\title{
Maqamat Tokoh Midah Dalam Novel Mekkah: Memoar Luka Seorang TKW Karya Aguk Irawan
}

\author{
Siswoyo Aris Munandar ${ }^{1}$, Farida Nurus Sofa ${ }^{2}$ \\ ${ }^{1}$ Ilmu Tasawuf, Fakultas Usuluddin, Sekolah Tinggi Agama Islam Sunan Pandanaran Yogyakarta, \\ Jl. Kaliurang Km 12.5, Candi, Sardonoharjo, Ngaglik, Sleman, Yogyakarta, 55581 Indonesia. \\ ${ }^{2}$ Ilmu al-Qur'an dan Tafsir, Fakultas Usuluddin, Sekolah Tinggi Agama Islam Sunan Pandanaran Yogyakarta, \\ Jl. Kaliurang Km 12.5, Candi, Sardonoharjo, Ngaglik, Sleman, Yogyakarta, 55581 Indonesia. \\ Penulis untuk Korespondensi/E-mail: siswoyoaris31@gmail.com
}

\begin{abstract}
Abstrak - Aguk Irawan adalah salah satu sastrawan yang menggunakan sastra novel sebagai media dakwahnya. Penanaman pesan-pesan moral-spiritual penulis kepada pembaca melalui tokoh yang dihidupkan di dalamnya. Peneliti tertarik dengan salah satu karya beliau untuk diteliti yang kemudian terangkum dengan judul, "Maqamat Tokoh Midah dalam Novel Mekkah: Memoar Luka Seorang TKW Karya Aguk Irawan". Novel yang terinspirasi dari kisah nyata ini menggambarkan tentang pengembaraan jiwa seorang perempuan dalam menemukan Tuhannya. Penelitian ini menggunakan metode library research atau penelitian kepustakaan. Adapun sumber data yang digunakan adalah sumber data primer yaitu novel Mekkah: Memoar Luka Seorang TKW, sedangkan sumber data sekundernya adalah beberapa karya Aguk Irawan yang lain dan juga sumber referensi yang terkait dengan penelitian. Berdasarkan hasil analisa yang telah peneliti lakukan dapat ditarik kesimpulan bahwa novel Mekkah: Memoar Luka Seorang TKW merupakan novel yang mengandung ajaran tasawuf. Aguk Irawan menyampaikan ajaran tasawufnya melalui tokoh Midah Hamidah yang terangkum dalam laku kehidupannya sehari - hari. Peneliti menemukan beberapa maqamat yang tergambar dari tokoh Midah Hamidah, diantaranya adalah: taubat, zuhud, sabar, syukur, dan ridha. Novel karya Aguk Irawan ini sangat berguna untuk digunakan sebagai media dakwah di kalangan remaja maupun masyarakat pada umumnya.
\end{abstract}

Abstract - Aguk Irawan is one of the writers who used novel literature as his propaganda media. Planting the writer's moral-spiritual messages to the reader through the characters who are turned on in them. Researchers are interested in one of his works for research which is then summarized with the title, "Maqamat Tokoh Midah dalam Novel Mekkah: Memoar Luka Seorang TKW Karya Aguk Irawan". This novel, inspired by a true story, depicts the wandering of a woman's soul in finding her God. This research uses library research or library research. The source of the data used is the primary data source, namely the Mecca novel: Memoirs of Luka of a TKW, while the secondary data source is some of Aguk Irawan's other works and also a reference source related to research. Based on the results of the analysis that researchers have done, it can be concluded that the novel Mecca: Memoirs of Luka of a $T K W$ is a novel that contains the teachings of Sufism. Aguk Irawan conveyed his Sufism teachings through the figure of Midah Hamidah summarized in his daily life. Researchers found several maqamat drawn from the Midah Hamidah figures, including repentance, zuhud, patience, gratitude, and pleasure. This novel by Aguk Irawan is very useful to be used as a media for da'wah among teenagers and the general public.

Keywords - Literary works, Novels, Maqamat, Spirituality, Hermeneutics

\section{PENDAHULUAN}

$\mathrm{S}$ ejarah tasawuf telah membuktikan bahwa sastra merupakan salah satu media yang sangat penting untuk menyampaikan pengalaman kerohanian masing-masing para sufi [1]. Cara penyampaian pengalaman kerohanian para sufi dituangkan dalam bentuk sastra puisi, anekdot, alegori, dan atau kisah perumpamaan (novel). Sebagian besar dari para sufi tidak berniat untuk 
menuliskan pengalaman kerohanian mereka dalam bentuk karya sastra. Hal ini menjadi sangat wajar jika menilik dari sejarah masa Rasulullah, saat itu karya sastra, khususnya puisi atau syair, merupakan sebuah fenomena yang sangat diagungkan. Para sufi percaya bahwa keindahan yang tertuang dalam sebuah karya sastra akan mampu membangunkan cinta yang telah tidur di dalam hati. [2]

Para sufi klasik banyak yang menggunakan karya sastra dalam mengembangkan dakwahnya. Seperti dalam bentuk kitab, syair, puisi, dan lain sebagainya. Tulisan-tulisan yang dituangkan biasanya berisi tentang pengalaman pribadinya selama menjalani kehidupan sebagai seorang sufi. Selain itu juga berisi tentang petuah-petuah kepada orang-orang yang akan menjalani kehidupan spiritual, seperti kitab al-Hikām karya Ibn Athāillah as-Sakandarī, Adab asSulūk wa at-Tawāsul ilā Manāzil al-Mulūk karya Syekh Abd al-Qādir al-J̄̄lā nī. Keberhasilan dakwah yang dilakukan oleh para ulama terdahulu memberi inspirasi para ulama modern untuk mensyiarkan dakwah menggunakan metode yang sama. Penyisipan nilai-nilai moralspiritual dalam suatu bentuk karya untuk menyebarkan dakwah telah diakui menjadi metode yang paling berhasil. Salah satu contoh keberhasilan dakwah Islam melalui karya sastra adalah keberhasilan memasukkan ajaran-ajaran Islam ke Indonesia [3].

Seni sastra yang berkembang di Indonesia ada beberapa macam, yaitu: hikayat, babad, sejarah, suluk, syair, syiir dan sebagainya. Hikayat merupakan cerita dongeng belaka [4]. Beberapa contoh hikayat ini antara lain Hikayat Pendawa Lima, Hikayat Seri Rama, Hikayat Pancatanderan. Adapun cerita yang sengaja disusun sebagai cerita sejarah disebut babad, contohnya antara lain Babad Tanah Jawi, Babad Giyanti. KH. Mustofa Bisri (yang sering kita kenal dengan sebutan Gus Mus) merupakan seorang ulama yang juga dikenal sebagai seorang sastrawan. Gus Mus telah banyak menciptakan puisi yang sangat melegenda. Salah satu karya puisinya yang sangat terkenal adalah puisi yang berjudul "Lirboyo". Emha Ainun Najib (yang sering kita kenal dengan sebutan Cak Nun) juga menyampaikan dakwahnya melalui sebuah karya. Berbeda dari Gus Mus dengan puisinya, Cak Nun mempunyai majlis dakwah yang disebut dengan "Maiyah". Majlis dakwah Cak Nun selalu ramai oleh para jamaah, baik dari kalangan muda sampai kalangan tua.
Metode dalam berdakwah bisa menggunakan lisan ataupun tulisan. Dakwah dengan lisan, seperti dalam majlis pengajian Cak Nun. Adapun dakwah dengan tulisan bisa dituangkan dalam bentuk kitab, syair, puisi, novel, dan sebagainya. Dakwah menggunakan tulisan juga telah terbukti menjadi salah satu metode yang paling praktis, karena dalam menjalankan dakwah tidak menggunakan paksaan sama sekali. Keberhasilan dakwah ini menjadi salah satu hal yang menarik untuk dikaji. Telah banyak kajian yang dilakukan bersangkutan dengan tema tersebut. Peneliti di sini juga ingin mencoba mengkaji salah satu karya sastra yang di dalamnya terdapat pesan yang perlu dikaji lebih dalam [5].

Peneliti mengambil salah satu karya sastra sebagai objek penelitian, dalam hal ini berupa karya sastra tulisan yang dituangkan dalam bentuk novel. Adapun novel yang akan dikaji berjudul: "Mekkah: Memoar Luka Seorang TKW" karya Aguk Irawan. Peneliti menemukan sesuatu yang menjadi ketertarikan dalam penelitian ini yaitu kisah dalam novel yang diceritakan diangkat dari kisah nyata. Seorang gadis, anak dari seorang kiai desa yang hidup dalam ajaran luhur tentang kehidupan. Bahwa manusia merupakan makhluk Tuhan yang diciptakan untuk menyembah-Nya. Ajaran agama tentang tatacara beribadah sampai pengolahan hati agar senantiasa dekat dengan Allah merupakan makanan sehari-hari. Cobaan demi cobaan yang menimpa dijadikan sebagai perantara kedekatan seorang hamba dengan Tuhannya [6].

Perjalanan hidup membawanya menjadi seorang TKW di Makkah. Negara di mana seorang asisten rumah tangga masih dianggap sebagai budak oleh majikannya. Begitu pula yang dialami oleh Midah Hamidah, tokoh utama dalam novel Mekkah: Memoar Luka Seorang TKW. Upaya pendekatan dirinya kepada Allah semakin diuji dengan keadaan hidup yang semakin berat. Usaha demi usaha serta tekad dan kecintaannya kepada Allah pada akhirnya membuahkan hasil. Dijelaskan bahwa perjalanan hidup Midah mirip dengan seorang sufi perempuan Rabi'ah al-Adawiyah.

Berdasarkan latar belakang masalah yang telah diuraikan di atas, fokus persoalan yang akan ditemukan jawabannya dalam penelitian ini dirumuskan sebagai berikut: Pertama, Apa saja maqamat yang terdapat pada tokoh Midah dalam novel Mekkah: Memoar Luka Seorang TKW Karya Aguk Irawan? Kedua, Bagaimana cara pengamalan tasawuf yang digambarkan oleh tokoh Midah dalam 
novel Mekkah: Memoar Luka Seorang TKW Karya Aguk Irawan?

Adapun tujuan dari penelitian ini adalah: Pertama, Mengetahui maqamat yang terdapat pada tokoh Midah dalam novel Mekkah: Memoar Luka Seorang TKW Karya Aguk Irawan? Kedua, Mengetahui corak tasawuf yang digambarkan oleh tokoh Midah dalam novel Mekkah: Memoar Luka Seorang TKW Karya Aguk Irawan? Secara umum penelitian ini mempunyai manfaat untuk menginspirasi para peneliti selanjutnya untuk menggali maqamat yang terkandung dalam karya sastra. Sangat disayangkan apabila banyak karya sastra tasawuf yang tidak bisa diakses oleh khalayak. Pesan moral yang disampaikan oleh para peneliti mempunyai nilai yang sangat tinggi untuk diketahui. Boleh jadi selama ini orang telah banyak membaca akan tetapi tidak mendapatkan maksud yang sebenarnya disampaikan oleh peneliti. Dengan adanya penelitian ini maka diharapkan agar para pembaca sedikit banyak mendapat manfaat dari apa yang dibacanya.

Secara khusus penelitian ini memberikan kontribusi terhadap khazanah keilmuan khususnya dalam bidang tasawuf. Melalui karya sastra, tasawuf menampakkan sisi keindahannya. Sisi keindahan yang oleh para ulama Islam masa awal (di Indonesia) banyak disisipkan dalam karya sastra sebagai media dakwah. Sudah tidak terhitung berapa banyak karya sastra para ulama yang mengandung pesan tasawuf. Salah satu ulama yang paling terkenal dengan keberhasilan dakwah melalui karya sastra yaitu Sunan Kalijaga. Sunan Kalijaga telah menciptakan banyak syair, suluk, kitab, maupun cerita-cerita rakyat yang mengandung pesan tasawuf yang sangat tinggi. Berkiblat pada keberhasilan-keberhasilan tersebut, peneliti sangat berharap bahwa penelitian ini dapat membantu para pecinta sastra mendapat pesan yang disisipkan dalam novel Mekkah: Memoar Luka Seorang TKW Karya Aguk Irawan.

\section{METODE}

Penelitian ini merupakan penelitian kualitatif yang didukung oleh data lapangan. Pendekatan yang peneliti gunakan adalah teori hermeneutik Hans Georg Gadamer. Hermeneutika Gadamer terdiri dari tiga titik poin penting yaitu pembaca, teks, dan peneliti. Saat pembaca mulai membaca teks maka muncul prasangka dan pertanyaan. Prasangka dan pertanyaan merupakan proses dari sebuah pemahaman. Pemahaman yang dimaksud oleh Gadamer bukanlah memahami kalimat tersebut, tetapi proses bagaimana sang pembaca berusaha menguji dan membuktikan prasangkaprasangkanya. Prasangka tidak hanya berasal dari pembaca, prasangka juga berada di dalam teks yang berasal dari pengarangnya sendiri, yaitu berupa pernyataan-pernyataan. Pembaca harus membiarkan dua hal tersebut berhadapan, sehingga makna yang akan dipahami lebih luas dari makna pengarang sesungguhnya. [7].

Sumber data terbagi menjadi dua kelompok, yaitu sumber data primer dan sekunder. Adapun sumber data primer adalah sumber pokok sebagai objek penelitian, dalam hal ini adalah Novel Mekkah: Memoar Luka Seorang TKW. Sedangkan sumber data sekunder yaitu data-data pendukung yang dibutuhkan untuk mendukung data primer [8]. Dalam teknik pengumpulan data Penulis menggunakan 2 teknik pengumpulan data dalam penelitian ini, pertama adalah teknik baca dan catat, dan kedua melalui wawancara. Pertama, penulis menggunakan teknik baca dan catat yaitu penulis membaca novel Mekkah: Memoar Luka Seorang TKW karya Aguk Irawan secara menyeluruh untuk mengetahui identifikasi secara umum, lalu membaca secara cermat untuk mencari nilai-nilai tasawuf dalam novel tersebut dengan mencatat kutipan-kutipan atau dialog-dialog yang menunjukkan adanya nilai tasawuf khusunya dalam maqamat. Kedua, penulis melakukan wawancara kepada bapak Aguk Irawan selaku penulis novel guna memenuhi laporan penelitian, kemudian mencari bahan seperti buku, skripsi, jurnal dan lainnya yang mempunyai kecocokan dalam pembahasan ini sehingga dapat membantu penulis dalam menyelesaikan penelitian ini. [9].

Adapun metode yang digunakan untuk mengelola atau menganalisis data yakni deskriptif dan analisis. Pertama, metode deskriptif yakni metode penelitian yang memaparkan suatu keadaan, objek, perilaku tertentu kemudian dianalisis. [10]. Sehingga, di sini akan dijelaskan dan diuraikan bagiamana isi novel Mekkah: Memoar Luka Seorang TKW melalui pendekatan interpretasi makna menggunakan hermenuetik. Dua fokus dalam hermeneutik yakni peristiwa pemahaman teks dan persoalan yang lebih mengarah pada mengenai apa itu pemahaman dan interpretasi. Karya sastra dipandang sebagai sebuah teks yang mana cenderung dinyatakan sebagai sebuah objek-objek estetik. Oleh karenanya, teks dianalisis dalam pemisahan tegas dari unsur subjek 
dan analisisnya dianggap sebagai kata lain interpretasi. [11]

Tugas interpretasi harus membuat sesuatu yang kabur, jauh dan gelap maknanya menjadi sesuatu yang jelas, dekat dan dapat dipahami. Konsep lingkaran hermeneutis merupakan pijakan dasar dalam menganalisis karya sastra, yaitu interaksi dialektis antara keseluruhan dan bagian, kemudian masing-masing memberikan makna lagi, dengan begitu pemahaman merupakan lingkaran hermeneutis. Kedua, teknik analisis, yaitu mereduksi data kajian dengan memilah dan memilih data supaya data yang diambil sesuai dengan tujuan penelitian.

\section{HASIL DAN PEMBAHASAN}

\section{Maqamat dan Tasawuf}

Membahas mengenai tasawuf tidak terlepas dari pembahasan tentang derajat kedekatan seorang sufi kepada Tuhannya. Derajat kedekatan seorang sufi disebut dengan istilah maqam. [12]. Istilah maqam sering disebut dengan ungkapan jamaknya yaitu maqamat. Secara harfiah maqamat merupakan jamak dari kata maqam yang berarti tempat berpijak atau pangkat mulia. Maqamat dalam ilmu tasawuf berarti kedudukan hamba dalam pandangan Allah berdasarkan apa yang telah diusahakan, baik melalui riyadhah, ibadah, maupun mujahadah. Maqamat juga dapat diartikan sebagai jalan panjang atau fase-fase yang harus ditempuh oleh seorang sufi untuk berada sedekat mungkin dengan Allah. Maqam dilalui seorang hamba dengan usaha yang sungguh-sungguh dalam melakukan seluruh rangkaian kewajiban dalam jangka waktu tertentu. Seorang hamba tidak akan mencapai maqam berikutnya sebelum menyempurnakan maqam sebelumnya.

Maqamat dapat diartikan dengan tingkatan, yakni tingkatan hidup yang telah dicapai oleh seseorang. Tingkatan tersebut dapat terlihat dari akhlak atau tindak-tanduk seseorang dan amal perbuatan orang tersebut. Maqam dapat dicapai dengan kesungguhan yang terus menerus selalu dilakukan. Seseorang akan dapat naik menuju maqam yang lebih tinggi apabila dia telah mampu melaksanakan syarat-syarat yang ada dalam maqam tersebut secara konsisten. Al-Qusyairi berkata, "barangsiapa yang belum menyempurnakan maqam qana'ah (merasa cukup), ia tidak akan mencapai maqam tawakkal, dan barangsiapa yang belum menyempurnakan maqam tawakkal, ia tidak akan dapat mencapai maqam taslim (penyerahan diri) kepada Allah. Demikian juga kalau belum sempurna maqam taubat, ia tidak akan mencapai maqam inabah, dan sebelum sempurna maqam wara ${ }^{e e}$ tidak akan mencapai maqam zuhud." [13].

Menurut M. Subkhan Anshori Maqamat adalah ungkapan tentang etika yang diemban oleh setiap murid untuk sampai pada tujuan yang berupa kesirnaan diri (fana) dalam diri al-haq. Di mana dalam tiap maqam, terdapat suatu mujahadat (perjuangan), riyadhah (olah diri), dan suluk (jalan) yang terejawantahkan dalam wara', tawakal, sabar, zuhud, dan lain sebagainya [14]. Seorang salik tidak bisa beralih dari satu maqam menuju maqam berikutnya sebelum melaksanakan segala tuntutan maqam yang sedang dilaluinya secara tuntas. Seorang sufi kadang memerlukan waktu sampai puluhan tahun hanya untuk berpindah dari satu maqam ke maqam yang lain [15]. Maqam berarti iqamah, sebagaimana kata al-madkhāl berarti idkhāl, dan al-makhrāj berarti al-ikhrāj. Tidak seorang pun sah menahapi suatu maqam, kecuali dengan penyaksian terhadap kedudukan Allah swt. tehadap dirinya dengan maqam tersebut, yang dengannya struktur bangunan ruhaninya benar menurut pondasi yang shahih [16].

\section{Jalan Tasawuf tokoh Midah dalam Novel Mekkah: Memoar Luka Seorang TKW}

Novel Mekkah karya Aguk Irawan merupakan novel yang mengandung tasawuf. Aguk menampilkan bahwa berdakwah bisa melalui berbagai metode, salah satunya adalah novel. Novel Mekkah: Memoar Luka Seorang TKW menceritakan tentang seorang anak desa di daerah Indramayu, Midah Hamidah namanya. Midah berasal dari keluarga yang kurang mampu secara ekonomi. Ayah Midah, Irfan adalah seorang kiai di desanya. Keluarga adalah madrasah pertama untuk anak-anak. Begitu juga yang terjadi dalam keluarga Midah. Ayah Midah selalu mengajarkan dan mencontohkan kepada Midah tentang bagaimana hidup yang sesuai dengan ajaran Islam. Midah kecil telah belajar banyak dari keluarganya tentang cara mengolah hati terhadap semua yang Allah gariskan dalam kehidupannya. Midah bahkan bisa lebih menyerap semua ajaran itu karena kepolosan dan kesucian hatinya. Kepolosan dan kesucian hati itulah yang menjadi kunci terpatrinya seluruh ajaran dan kebaikan. Disebutkan dalam suatu penggalan cerita tentang hakikat zuhud menurut ayah Midah dan Midah. Bahwa ayah Midah masih menjaga kehati-hatian agar hati tidak terpikat pada gemerlap dunia sehingga ia menolak untuk 
memperoleh dunia selain apa yang dibutuhkan saja. Sedangkan Midah berpendapat lain, ia menganggap bahwa dunia boleh saja dimiliki asalkan hati tidak mempunyai rasa kepemilikan atas harta itu. Latar belakang kehidupan kecil Midah yang penuh dengan ajaran dan falsafah hidup seperti itu sudah terlihat bahwa hal tersebut adalah perilaku hidup tasawuf.

Tokoh Midah yang digambarkan dalam novel ini, menurut peneliti setelah melakukan analisis, maka ada beberapa maqamat yang dilaluinya sampai pada akhirnya mencapai maqam Ridha. Peneliti menyebutkan ada lima maqamat, yaitu: Taubat, Zuhud, Sabar, Syukur, dan Ridha [17]. Berikut penjelasan dan analisisnya sesuai dengan pendapat tentang maqamat oleh al-Ghazali dalam kitab Ihya Ulumuddin:

$\underline{\text { Taubat }}$

"Dan bertobatlah kamu sekalian kepada Allah".

Taubat adalah wajib bagi setiap manusia. Kewajiban bertaubat ada karena manusia tak ada yang luput dari dosa. Baik dosa yang dilakukan dengan anggota tubuhnya ataupun yang dilakukan oleh hatinya, yaitu salah satunya lalai kepada Allah. Manusia adalah makhluk ciptaan Tuhan yang paling sempurna dengan dibekali akal dan juga nafsu. Akal dan nafsu itulah yang membedakan antara manusia dengan makhluk Tuhan lainnya. Manusia bisa menentukan atau mengupayakan takdir dirinya dengan usahanya. Jika tidak bisa mengontrol dirinya dari nafsu yang dapat merusak fitrahnya, maka celakalah ia. Namun begitu Tuhan adalah Dzat Yang Maha Pengampun. Sehingga seberapapun kesalahan atau dosa yang telah dilakukan akan dihapus apabila dia bertaubat dan berusaha untuk tidak mengulangi kesalahannya serta berupaya untuk berbuat hal-hal yang baik [18].

Namun begitu ada juga manusia yang walaupun tidak berbuat sesuatu yang dilarang, masih merasa dirinya hina. Sehingga dia terus menerus mendekat dan memohon ampun serta petunjuk kepada Tuhan. Ia juga akan senantiasa menghiasi dirinya dengan sifat-sifat yang baik dan menjaga dari sifat-sifat buruk. Penggalan cerita berikut adalah gambaran bahwa tokoh Midah berada dalam maqam taubat. Hal 13

"tidaklah mengherankan jika kehidupan yang dilalui keluarga Midah Hamidah hari demi hari senantiasa terbingkai oleh pesanpesan agama. Sebuah keluarga yang sederhana dan bersahaja. Laku hidup mereka itu berlandaskan pada ayat-ayat dan hadis-hadis yang sudah dihapal Irfan dan semuanya memberi isyarat tentang betapa rendahnya dunia jika dibanding dengan akhirat, betapa hinanya dunia jika dibanding dengan kemuliaan akhirat".

Sejak kecil Midah telah terbiasa dengan keadaan hidup yang serba kekurangan, namun dengan ajaran agama yang selalu ditanamkan Irfan kepadanya, ia menjadi seorang yang kuat imannya.

Zuhud

Zuhud merupakan sikap berpaling dari sesuatu yang sifatnya sementara kepada sesuatu yang sifatnya kekal. Ibarat orang tidak suka kepada dunia karena berpaling kepada akhirat atau ia berpaling dari sesuatu yang selain Allah kepada Allah. Zuhud merupakan sesuatu yang sulit dilakukan bagi seseorang yang dalam hatinya kurang dalam menghadirkan Allah. Sulit bukan berarti tidak bisa, seseorang akan dapat mencapai maqam zuhud dengan olah lahir dan batin setiap hari tanpa henti [19]. Beberapa contoh sikap zuhud yang terlihat dalam novel Mekkah adalah diantaranya:

"suatu hari, tamir masjid menyarankan agar Irfan merenovasi rumah itu hingga menjadi lebih baik dan layak dihuni oleh seorang ustadz seperti dirinya. Tapi saran itu ditolak dengan tegas oleh ustadz Irfan, karena ia takut pada hal-hal yang syubhat. Barangkali bukan hanya karena syubhat, yang lebih penting adalah dari itu adalah: Irfan takut kalau-kalau ia terjerumus pada cinta yang berlebihan pada harta benda, termasuk rumah itu".

Meninggalkan sesuatu yang bersifat syubhat adalah contoh sikap zuhud. Menjaga atau melatih hati dari mencintai selain kepada Allah merupakan salah satu sikap zuhud yang digambarkan melalui tokoh Irfan sebagai ayah Midah. Sikap zuhud seperti dalam penggalan cerita tersebut adalah zuhudnya orang dalam maqam zuhud awal. Ia masih sangat berhatihati karena takut apabila memiliki harta dunia maka ia akan mencintainya sehingga melupakan Allah.

"Bagi Midah, tidak ada salahnya membangun rumah yang layak asalkan hati dan iman sudah tak tergoyahkan oleh nafsu yang membelenggunya. Ayat-ayat yang dibacakan oleh ayahnya itu tidak menganjurkan manusia 
untuk mencaci maki dunia, tapi justru mengajarkan bagaimana caranya agar manusia mengubah sifat harta yang sementara, semu, dan menipu itu menjadi bermanfaat dan kekal di sisi-Nya, dan bisa menemani manusia hingga ke Padang Mahsyar, dan menuju surga."

Penggambaran sikap zuhud melalui tokoh Midah dalam penggalan cerita tersebut adalah sikap zuhud orang yang sudah tidak khawatir dirinya akan mencintai dunia. Ia yakin bahwa memiliki dunia tidak berarti dirinya akan mencintainya. Dunia baginya adalah alat atau perantara untuk semakin mendekatkan dirinya kepada Allah. Harta yang dimiliki digunakan untuk membuat tempat ibadah agar memudahkan orang mendekat kepada Allah. Harta yang dimiliki digunakan untuk membantu saudara dari musibah, misalnya kelaparan. Seseorang dengan sikap seperti ini tidak khawatir apabila sewaktu-waktu harta yang dimiliki hilang dari tangannya, karena dia tidak mencintainya. Dunia ada dalam genggamannya namun tidak dalam hatinya. Sikap seperti ini menandakan bahwa seseorang telah matang dalam maqam Zuhud.

\section{$\underline{\text { Sabar }}$}

Sabar merupakan salah satu tingkatan maqamat dalam tasawuf. Sabar adalah sifat yang hanya ada pada manusia sebagai makhluk yang paling sempurna. Sabar terbagi menjadi dua, yaitu sabar jasmani dan rohani. Sabar jasmani yaitu menerima atau tidak melawan ketika mendapat cobaan yang berkaitan dengan jasmani seperti mendapatkan penyakit atau tertimpa musibah [20]. Sabar rohani adalah sabar dalam menahan godaan hawa nafsu, seperti ketika melihat sesuatu yang mendorong pada perbuatan maksiat. Sabar memiliki beberapa ciri-ciri, yaitu diantaranya: a. tidak mengeluh terhadap cobaan yang menimpanya, b. tidak menyerah untuk tetap berusaha meski telah gagal, c. tidak menampakkan kesedihan (ketika sedang tertimpa musibah) di depan umum [21].

Novel Mekkah: Memoar Luka Seorang TKW menggambarkan banyak contoh sifat sabar. Salah satunya terlihat pada keluarga Midah ketika ayah Midah, ustaż Irfan meninggal.

"Sejak peristiwa itulah mendung duka seolah turun ke Bumi. Duka Yuyun, emak Midah, tak tertahankan. Ia tidak hanya harus menerima kenyataan pahit bahwa suami yang dicintainya mati di tangan warga desa, tapi juga harus menanggung fitnah yang keji. Suaminya dituduh maling. Saat itu ia sedang mengandung anak kelimanya. Tulang punggung keluarganya telah meninggal, entah kepada siapa lagi ia harus menyandarkan hidupnya. Sementara Midah, anak sulungnya, baru duduk di kelas tiga aliyah sambil nyantri di desa sebelahnya. Anak keduanya masih kelas dua tsanawiyah yang juga nyantri di tempat yang sama dengan Midah. Anak ketiganya duduk di kelas enam madrasah ibtidaiyah, dan anak keempatnya masih TK. Emak Midah mau tidak mau harus menjadi tulang punggung keluarganya menggantikan suaminya. Apapun yang terjadi, anak-anaknya harus tetap melanjutkan pendidikannya". "Emak Midah menjual gorengan yang dibantu dijajakan oleh anak ketiganya. Akan tetapi usaha itu tidak bertahan lama karena harga bahan-bahan yang terus melonjak naik. Sampai suatu hari Midah pulang untuk meminta uang guna membayar biaya ujian akhir. Emak hanya bisa menangis. Bertahan hidup saja mereka hampir-hampir tidak bisa. Makan hanya sekali sehari, itupun dengan nasi aking. Bukan dengan beras raskin yang entah kenapa tidak pernah sampai pada mereka. "Sabar Nak! Mungkin kemiskinan keluarga kita adalah wujud rasa sayang Allah yang besar pada kita." Midah menjawab, "jadi apa yang harus aku perbuat mak? Aku ingin membantu emak!”.

Indikasi kesabaran yang terlihat pada Midah dan keluarganya saat itu.

Terlepas dari ditinggal mati salah seorang anggota keluarga, adalah pertama, bahwa emak Midah harus mencari nafkah untuk memenuhi kebutuhan hidup sehari-hari menggantikan suaminya. Kedua, adik-adik Midah harus membantu emak Midah berjualan dalam usia yang masih di bawah umur. Ketiga, Midah harus berhenti dari sekolah dan pesantren menjelang ujian akhir karena tidak ada biaya. Midah juga harus membantu emaknya untuk menjadi tulang punggung keluarga dengan bekerja serabutan, kadang menjadi tukang cuci tetangganya, juru masak pada acara-acara hajatan, dan sebagainya.

Contoh kesabaran yang telah penulis jabarkan tersebut termasuk dalam kesabaran jasmani. Adapun yang termasuk dalam kesabaran rohani dari cobaan tersebut adalah bahwa Midah dan keluarga harus menanggung rasa sakit hati karena kematian ayah Midah "terlihat" tidak terhormat "Penulis menggunakan kata "terlihat" karena cara kematian 
ayah Midah memang seperti tidak terhormat, yaitu meninggal karena salah sasar amukan warga. Akan tetapi, melihat dari kisah hidup ayah Midah yang selalu mengabdikan dirinya sebagai hamba Tuhan, cara kematiannya sangat mungkin menyimpan hikmah yang besar dibaliknya". Ayah Midah meninggal karena salah sasar amukan warga yang sedang terburu-buru mengejar pencuri. Orangorang yang tidak mengerti dengan situasi tersebut akan berpikir bahwa ayah Midah adalah seorang pencuri.

"tanah di belakang rumah, satu-satunya kekayaan keluarga itu terpaksa dijual oleh Emak, untuk biaya pengurusan paspor Midah, juga biaya surat-surat, calo, dua bulan pelatihan di tempat penampungan dan tentu saja setoran untuk PT. PRIMA ANGKASA, perusahaan jasa tenaga kerja yang memberangkatkan Midah ke Saudi Arabia”

Paragraf di atas menunjukkan bahwa Midah dan keluarganya sangat bersabar atas segala cobaan yang menimpanya. Mereka tidak berlarut-larut dalam kesedihan. Mereka justru menunjukkannya dengan berusaha sekuat tenaga untuk bangkit, salah satunya dengan bekerja menjadi seorang TKW. Keputusan untuk bekerja di negeri orang bukanlah keputusan yang mudah. Kalau saja keadaan tidak se-mendesak ini, maka bekerja menjadi TKW tidak akan pernah dilakukan.

\section{$\underline{\text { Syukur }}$}

Syukur merupakan ungkapan terima kasih atas sesuatu yang datang dengan mempergunakan sesuatu itu dengan sebaik-baiknya. Allah adalah satu-satunya żat pemberi nikmat. Dia-lah yang membuat matahari bersinar, bulan bercahaya sehingga malam menjadi terang [22]. Tidak terhitung berapa banyaknya nikmat yang telah Allah berikan untuk setiap makhluknya. Dalam alQur'an QS. Ibrahim [14]: 34 Allah berfirman yang artinya:

"dan Dia telah memberikan kepadamu (keperluanmu) dan segala apa yang kamu mohonkan kepadanya. dan jika kamu menghitung nikmat Allah, tidaklah dapat kamu menghinggakannya. Sesungguhnya manusia itu, sangat zalim dan sangat mengingkari (nikmat Allah)".

Tokoh Midah dalam Novel Mekkah juga senantiasa bersyukur kepada Allah meski dalam kesulitan sekalipun. Midah sudah terbiasa dengan kehidupan sederhana, sehingga untuk menjadi seorang TKW di negeri orang pun ia masih bersyukur. Rasa syukurnya menjadi semakin besar tatkala Midah mengetahui bahwa ia akan bekerja di kota Mekkah. Kota yang selalu di impikan oleh seluruh umat Muslim di dunia. Kesempatan menginjakkan kaki di kota suci tidak datang kepada semua orang. Midah merasa kesempatan tersebut sebagai panggilan dari Tuhan kepadanya.

"Ada sesuatu yang sedang bergemuruh di dadaku, aku benar-benar bahagia. Nikmat yang besar ini wajib kusyukuri. Betapa tidak? Seorang anak desa yang polos dan miskin, kini sedang berada di tengah-tengah kota Mekkah. Alhamdulillāhi rabbi al-ālamīn. Dari sekian banyak TKW yang diberangkatkan ke Saudi, tidak sampai lima persen yang ditempatkan di Mekkah. Tapi aku adalah salah satu yang mendapatkan impian itu. Bagiku, kota Mekkah tidak sekedar kota yang bersejarah dan berlimpahan kemuliaan, tapi juga karena dengan tinggal di kota ini aku merasa aman, sebagaimana yang dijanjikan Allah dalam alQur'an".

Pernyataan tokoh Midah pada paragraf di atas adalah salah satu bentuk ungkapan syukurnya kepada Tuhan. Ia masih senantiasa merasa perlu berterimakasih saat cobaan yang berat sedang menimpanya. Besarnya cobaan yang Allah berikan tidak lantas melunturkan keimanan yang ada dalam diri Midah. Midah selalu bisa mengambil hikmah dari setiap cobaan yang diberikan.

$\underline{\text { Ridha }}$

Pencapaian maqam Ridha yang dialami oleh tokoh Midah bukanlah hal yang mudah dan secara langsung akan tetapi melalui perantara. Novel Mekkah memang adalah tasawuf yang menceritakan perjalanan menemukan Tuhan melalui perantara cinta kepada makhluk. Midah sebelum pada akhirnya menemukan hakikat cinta yang hakiki yaitu hanya kepada Allah saja, ia pernah mencintai makhluk Allah, Firdaus, dengan sangat tulus. Sebagai seorang pecinta, Midah ingin memberikan apa yang bisa ia lakukan demi seorang yang dicintainya. Hal ini terbukti salah satunya menjadi saksi atas kasus fitnah Firdaus yang memperkosa dokter Tien.

"Aku sudah rela menerima semua derita ini. Aku sudah menduga, nasibku memang akan berjalan seperti ini. Sebab saat aku menjadi saksi di persidanganmu, aku adalah TKW illegal. Aku tidak menyesal karena aku melakukannya demi cinta. Aku ingin menjadi pelayan cintaku." 
Midah begitu tulus mencintai, sampai suatu ketika Firdaus terbutakan oleh kecantikan fisik orang lain yang justru menjerumuskannya, Midah masih tetap mencintainya. Akan tetapi Midah sadar bahwa perasaan cinta dan pengharapan kepada makhluk hanya akan mengakibatkan kekecewaan Firdaus menjadi perantara Midah dalam menemukan cinta sejatinya, yaitu Allah. Cinta kepada Allah adalah cinta yang sebenar-benarnya cinta. Cinta kepada Allah mendatangkang ketentraman dan kenyamanan meskipun melalui derita sekalipun. Rasa cinta itulah yang kemudian mendatangkan keridhaan, atau perasaan rela dan bahagia dalam keadaan apapun. Ridha merupakan maqam terakhir dalam dunia kesufian.

Maqam ridha merupakan maqam tertinggi yang dapat dialami oleh orang-orang yang dekat dengan Allah [23]. Maqam ridha hanya dapat dicapai setelah sebelumnya lulus dari maqam taubat, zuhud, sabar, serta syukur. Ridha yaitu menerima dengan sukacita apapun keputusan yang Allah berikan. Ia meyakini dengan hatinya bahwa segala sesuatu yang Allah berikan adalah karena Allah menyayanginya sehingga ia merasa bahagia [24]. Al-Ghazali mengatakan bahwa ridha adalah buah dari rasa cinta (mahabbah). Ketika perasaan cinta kepada Allah sudah kuat, maka melakukan segala ketentuan dari yang dicintai merupakan suatu kebahagiaan [25]. Berikut merupakan beberapa ungkapan yang mengarah pada maqam ridha:

"Firdaus, derita tidak bisa dipisahkan dengan cinta. Sebab keduanya syarat untuk melayani keindahan".

Penderitaan adalah suatu bentuk cobaan yang diberikan oleh Allah kepada hamba-Nya. Allah ingin melihat apakah hamba-Nya mampu menghadapi cobaan tersebut. Penggalan dialog antara Midah dan Firdaus tersebut menandakan bahwa Midah telah dipenuhi perasaan cinta kepada Allah. Apapun yang diberikan Allah kepadanya bisa ia terima dengan penuh rasa cinta, dengan penuh suka rela. Midah paham bahwa perasaan cintanya sedang diuji, dan inilah pembuktian bahwa hatinya telah dipenuhi oleh rasa cinta kepada Allah semata.

"Aku rela menderita demi cinta. Kini aku sudah menemukan keindahan itu dan menerima takdir-Nya"

Segala sesuatu apabila dilakukan dengan cinta maka sepahit apapun akan tetap terasa manis. Seorang pecinta akan senantiasa dengan senang hati melakukan apapun demi rasa cintanya. Ia rela bahkan jika dirinya sendiri harus terluka. Karena luka itu sendiri sudah tidak terasa sakitnya.

"Besok aku akan diseret ke pengadilan dunia. Tidak apa-apa Firdaus! Meski ragaku disiksa, jangan risau Firdaus! Batinku tidak akan merasakan sakitnya cambukan itu sedikitpun. Keduanya akan berangkat ke arah yang berbeda dan berjalan dengan cara yang berbeda pula".

Penderitaan adalah sesuatu yang tidak pernah diinginkan oleh siapapun. Penderitaan identik dengan suatu cobaan. Di mata orang-orang yang memiliki cintalah penderitaan tak memiliki rasa sakit. Penderitaan menjadi sebuah kebahagiaan, karena itu pertanda bahwa Allah menyayanginya.

Orang-orang yang menyaksikan hukuman itu berteriak lantang,

"cambuk dan pukul dia, agar pelacur itu bertobat".

Midah masih saja berdiri, tidak menjawab perintah algojo untuk bersimpuh.

Lalu algojo bicara lagi, "dukuk dan bersimpuhlah! Kenapa engkau masih saja berdiri?"

Midah menjawab dengan suara lirih, "Aku memilih berdiri untuk menerima cambukanmu. Cambuklah aku sesukamu! Yang merasakan sakit hanya ragaku. Batinku tidak. Sesungguhnya batinku sudah sampai di keheningan yang panjang. Maafkan aku, aku tidak bermaksud menganggap remeh cambukanmu”.

Suasana hening sejenak, algojo mendengar ucapan Midah dengan seksama, lalu bertanya,"Batinmu sudah sampai di keheningan yang panjang, apa maksudnya, mujrimah?"

"Dia adalah pelabuhan terakhir cinta dan deritaku. Di sanalah hidupku bersemayam dalam keindahan". "bagaimana mungkin engkau hidup dalam keindahan, sedang tubuhmu kau jual pada laki-laki hidung belang? "Kau boleh berkata lebih busuk dari ini. Katakanlah hingga mulutmu memuntahkan kotoran yang paling menjijikkan. Aku sama sekali tidak tersinggung oleh kata-kata dari mulut busukmu itu. Sebab makna hurufku telah sampai. Ya, telah sampai kepada-Nya. Dia bukan lafadz atau kata, melainkan esensi".

Algojo kebingungan memaknai apa yang diucapkan Midah. Saat Midah masih berdiri sambil menengadahkan tangannya ke langit, ia langsung menghujamkan cambuknya berkali- 
kali. Di setiap pukulan, suara yang begitu jernih terdengar dari mulut Midah, "huwallah, huwallah, huwallah". Setelah cambukan kesepuluh, darah mulai membasahi baju Midah, merembes, dan beberapa tetas jatuh ke tanah. Dan pada cambukan yang kesekian kali, dengan sendirinya, Midah terpaksa bersimpuh di kaki algojo. Setelah cambukan genap mencapai angka delapan puluh kali, Midah jatuh terkapar di tanah lapang itu. Firdaus dan Marwan langsung lari mendekatinya, merengkuh jasad yang tergeletak bersimbah darah itu kemudian membawanya ke rumah sakit.

Pada hari kesekian Midah di rumah sakit, dengan mata terpejam, mulut Midah mengeluarkan kata-kata:

Kami berada di sini, kekasihku, kesaksian-Mu

Kami meminta perlindungan dari

pesona-Mu

Semoga engkau memberiku apa yang ingin aku raih

Rengkuh, gapai sebagai titik akhir makna hidupku

O, Engkau Tuhan langit dan bumi yang

bersinar

Ketika kami redup dalam simpuh-Mu

Sebagaimana engkau bersinar di depan para malaikat.

Dan setan remuk bentuk dari api-Mu

Aku adalah bentuk turun Adam hadir dalam, wicara-Mu

Engkau telah memberiku kesaksian-Mu

Ketika mereka menangkap, menuduh, dan mencemoohkanku

Aku hanya sendiri mengarungi waktu laut-Mu

Dalam bentuk yang indah dan

menakjubkan

Aku rela disiksa oleh tangan-tangan besi

Untuk mengucapkan perkataan yang memberiku kehidupan

Aku rela ditawan, dipenjara, diadili dan kemudian dihukum cambuk

Darahku mengalir bagai gurun, di tengah gelombang sungai Tigris

Tidak, tidak mungkin aku menyembunyikan$\mathrm{Mu}$ dari jiwa-Ku

Untuk memiliki-Mu semata. Aku rela hilang bentuk wujudku

Aku menangis kepada-Mu, bukan untuk diriku sendiri

Tetapi bagi jiwa-jiwa yang merindukan-Mu, yang saksinya
Aku sendiri, sekarang sampai kepada-Mu. Saksi keabadian

Seorang yang melakukan sesuatu atas dasar cinta, maka dia tidak akan pernah mengeluh seberapapun berat jalan dan rintangan yang akan dilalui. Ia justru menikmati setiap proses yang terjadi kepada dirinya. Cinta bisa mengubah sesuatu yang pahit menjadi terasa manis. Cinta bisa merubah sesuatu yang menyakitkan menjadi sesuatu yang amat menyenangkan [26]. Midah Hamidah adalah salah satu contoh bahwa cobaan yang berat adalah ujian dari rasa cintanya kepada Allah.

\section{Kontekstualisasi Tasawuf Tokoh Midah di Zaman Modern}

Novel Mekkah: Memoar Luka Seorang TKW Merupakan Novel Tasawuf

Novel Mekkah: Memoar Luka Seorang TKW merupakan novel tasawuf. Pernyataan ini terlihat dari penggambaran tokoh utama Midah Hamidah, seperti pada novel Aguk Irawan yang lainnya. Hal ini menjadi tanda bahwa semua tulisan Aguk Irawan mengandung ajaran tasawuf yang digambarkan melalui tokoh utamanya. Tasawuf yang digambarkan dalam novel ini mirip dengan jalan hidup seorang sufi perempuan Rabi'ah alAdawiyah.

Midah hidup di tengah keluarga miskin yang agamis. Sejak kecil Midah sudah menjadi anak yang shalihah, selalu menerima setiap cobaan yang menimpanya. Midah menjadi semakin dekat dengan Allah dan selalu hidup dalam kezuhudan. Kedekatannya kepada Allah menumbuhkan cinta yang mendalam di dalam hatinya. Kesibukannya menjadi seorang TKW di Mekkah tidak menyurutkan ibadahnya. Midah justru semakin mendekat kepada Allah disetiap waktu senggangnya.

Tumbuhnya rasa cinta yang sebenar-benarnya cinta Midah kepada Tuhan bukanlah murni dari Midah sendiri. Melalui perantara Firdaus lah Midah menemukan cinta yang hakiki. Rasa cinta Midah kepada Firdaus yang terhalang oleh orang ketiga diantara mereka. Firdaus lebih memilih orang lain daripada Midah karena kecantikan serta kekayaannya. Dua alasan itu justru membuat Firdaus celaka. Midah sebagai orang yang mencintai Firdaus merasa kecewa terhadap Firdaus, akan tetapi perasaan itulah yang kemudian mengantarkan Midah pada cinta kepada Allah. 
Urgensi Tasawuf di Zaman Modern

Penurunan spiritual di zaman modern adalah suatu hal yang sudah sangat sering terjadi. Peneliti mengambil contoh tentang kasus korupsi yang sudah sangat sering terjadi di Indonesia khususnya. Baru-baru ini terdengar kabar tentang kasus korupsi Dewan Perwakilan Rakyat Daerah (DPRD) kota Malang:

"Wakil Komisi Pemberantasan Korupsi (KPK) Basaria Panjaitan menyatakan Wali Kota Malang 2013 - 2018 Moch Anton bersama 18 anggota DPRD Kota Malang 2014-2019 telah melakukan korupsi secara massal, terkait kasus suap pembahasan APBD-P Pemkot Malang Tahun Anggaran 2015. "Kasus ini menunjukkan bagaimana korupsi dilakukan secara massal melibatkan unsur kepala daerah dan jajarannya serta sejumlah anggota DPRD yang seharusnya melakukan fungsi pengawasan, anggaran, dan regulasi secara maksimal," kata Basaria saat konferensi pers di gedung KPK Jakarta, Rabu $(22 / 3 / 2018)$ [27].

Korupsi dalam Kamus Besar Bahasa Indonesia (KBBI) adalah penyelewengan atau penyalahgunaan uang negara (perusahaan dan sebagainya) untuk keuntungan pribadi atau orang lain [28]. Kasus korupsi merupakan kasus yang sangat sering terjadi. Berita di atas merupakan satu contoh diantara ribuan kasus yang terjadi di Indonesia. Korupsi dilakukan bukan tanpa alasan. Menurut peneliti, ada beberapa faktor atau kemungkinan yang melatarbelakanginya.

Pendapat peneliti dalam tulisan ini berdasarkan pada sudut pandang tasawuf. Pertama, seorang yang melakukan korupsi adalah orang yang tidak memahami dirinya sendiri. Kedua, sadar atau tidak sadar, seorang tersebut lupa bahwa semua perbuatan yang dilakukannya diketahui oleh Allah swt. Ketiga, merasa kurang dan tidak bersyukur atas rezeki yang telah diberikan. Keempat, tidak menyadari bahwa perbuatan yang dilakukan akan merugikan diri sendiri dan orang lain, dan masih banyak lagi alasan lain yang melatarbelakanginya. Selain kasus tentang korupsi, ada juga kasus tentang pembunuhan. Pembunuhan selain melanggar hak asasi juga merupakan suatu perbuatan yang amat merugikan. Berikut salah satu contoh kasus pembunuhan yang terjadi:

"Bandung Barat - Deni Irawan (36) kaget bukan kepalang saat melihat ceceran darah di lantai rumah pegawai bank, Ella Nurhayati
(42). Deni tetangga Ella yang pertama kali mengetahui kejadian mengerikan tersebut. Ella tewas penuh luka tusuk di tubuhnya. Ella tinggal di rumahnya yang berlokasi di Kampung Pangragajian, RT 3 RW 9, Desa Kayuambon, Kecamatan Lembang, Kabupaten Bandung Barat. Di tempat tinggal tersebut, wanita berstatus janda tersebut diduga menjadi korban pembunuhan."

Pembunuhan bagaimanapun bentuknya merupakan suatu tindakan yang sangat keji dan melanggar hak asasi manusia. Ayat al-Qur'an menyebutkan bahwa nyawa harus dibayar dengan nyawa. Hal ini menjadi jelas bahwa kejahatan pembunuhan bukan merupakan sesuatu yang sepele apapun alasannya. Menurut peneliti, ada beberapa aspek yang terjadi ketika seseorang berani membunuh orang lain. Diantaranya adalah, pertama, aspek psikologis yang tidak normal. Kedua, kepekaan sosial yang rendah. Ketiga, spiritualitas yang tidak terisi dengan ajaran agama yang benar. Aspek ketiga adalah aspek yang akan dibahas dalam penelitian ini.

Pentingnya tasawuf di zaman modern semakin besar melihat tantangan kehidupan yang juga semakin banyak. Semakin canggihnya peradaban manusia, semakin banyak pula godaan yang menjauhkan orang dari jalan hidup beragama yang baik. Jika manusia kosong dari beragama maka otomatis jiwanya akan kering, kosong, hampa, dan sebagainya. Tasawuf merupakan penawaran yang cocok untuk permasalahan manusia modern [29]. Tasawuf memiliki dua aspek yaitu teoritis dan praktis. Aspek praktis tasawuf meliputi tata cara hubungan manusia dengan dirinya sendiri, dunia, dan Tuhan. Aspek praktis tasawuf disebut dengan sair wa suluk (perjalanan dan perlintasan) atau suluk saja. Suluk meliputi berbagai tahap (maqam) dan keadaan jiwa (hal). Suluk tersebut merupakan suatu jalan atau tahapan yang harus ditempuh agar manusia dapat senantiasa dekat dengan Tuhannya [30].

Taubat wajib dilakukan oleh semua manusia karena manusia merupakan makhluk yang tidak mungkin tidak pernah berbuat salah atau dosa. Perbuatan dosa yang dilakukan secara tidak disengaja dalam tasawuf tetap harus bertaubat, apalagi perbuatan dosa yang dilakukan secara sengaja. Hal ini menunjukkan bahwa Allah menginginkan makhluknya agar selalu mengingat-Nya dan selalu dekat dengan-Nya. Dua kasus yang peneliti ungkapkan dalam paragraf di atas adalah contoh 
perbuatan dosa yang dilakukan secara sengaja dan sering terjadi.

Kasus korupsi dan pembunuhan merupakan dua perbuatan yang sangat diharuskan untuk taubat. Peneliti menggunakan kata sangat diharuskan karena perbuatan tersebut tidak hanya merugikan diri sendiri tetapi juga merugikan orang lain. Adapun taubat yang perlu dilakukan adalah menyesal, meminta maaf kepada pihak yang bersangkutan (dalam hal ini korban atau orang lain yang terkena dampak dari perbuatannya), berjanji pada diri sendiri untuk tidak mengulangi kesalahan yang sama, mendekatkan diri kepada Allah dan memohon pengampunan dengan tujuan agar mendapat ketenangan hati. Ketenangan hati merupakan salah satu pondasi utama yang harus dimiliki oleh seseorang dalam bertasawuf. Ketenangan hati membawa pada kedamaian dan kebahagiaan serta pikiran yang positif. Pikiran positif sangat berpengaruh terhadap apa yang akan terjadi kepada seseorang yang memilikinya. Pikiran positif akan membawa seseorang untuk selalu menyikapi segala hal yang terjadi dalam hidupnya dengan positif.

Setelah bertaubat tahapan selanjutnya adalah berzuhud. Dilihat dari pengertian zuhud yaitu menjauhkan diri dari mencintai dunia, maka dalam konteks modern tentu berbeda dengan konteks pada masa abad awal ketika para sufi bersikap menghindari dunia. Zaman modern merupakan zaman dengan segala kemudahan dan canggihnya teknologi. Seseorang yang tidak mengikuti perkembangan zaman tentu akan menjadi orang yang tertinggal. Zuhud di zaman modern tidak harus meninggalkan dunia. Banyak dari kalangan orang yang mempunyai banyak harta justru mengikuti tarekat. Hal ini merupakan salah satu tanda bahwa kebahagiaan tidak bersumber pada harta dunia. Harta dunia berapapun yang dimiliki tidak akan pernah membuat pemiliknya merasa puas, sehingga salah satunya menjerumuskan pada korupsi. Korupsi tidak dilakukan oleh orang yang miskin (dalam kasus seperti yang telah peneliti uraikan), melainkan dilakukan oleh orang-orang yang tidak pernah merasa cukup. Kunci dalam zuhud adalah merasa cukup. Segala sesuatu yang diberikan oleh Allah merupakan yang terbaik bagi hambanya [31].

Haidar Bagir dalam bukunya mengutip beberapa kisah dan pendapat para ulama bahwa hidup bertasawuf bukan berarti harus hidup miskin. Salah satu kisah menceritakan tentang seorang yang selalu hidup sederhana, tetapi pada saat ia meminta nasihat dari gurunya yang hidup dengan banyak harta, gurunya itu menasihati agar ia tidak sibuk memikirkan dunia [32]. Begitulah seorang sufi, seorang yang terlihat hidup dalam kemiskinan belum tentu merupakan seorang sufi. Seseorang yang hidup bergelimang hatrta juga belum tentu tidak bisa menjadi sufi. Seorang sufi dinyatakan hidup zuhud apabila tangannya sibuk dengan urusan dunia namun hati tetap sibuk dengan urusan akhirat.

\section{KESIMPULAN}

Berdasarkan uraian yang sudah peneliti dapat disimpulkan bahwa penelitian dengan judul Jalan Tasawuf Tokoh Midah dalam Novel Mekkah: Memoar Luka Seorang TKW Karya Aguk Irawan berisi tentang maqamat yang tergambar dalam tokoh Midah. Pengambilan sudut pandang peneliti dalam menguraikan isi novel adalah menggunakan teori hermeneutika Gadamer. Sesuai dengan rumusan masalah yang peneliti kemukakan, dapat ditarik kesimpulan sebagai berikut:

Pertama, Maqamat yang terdapat dalam tokoh Midah diantaranya adalah: a. taubat, b. zuhud, c. sabar, d. syukur, e. ridha. Taubat adalah memohon ampunan kepada Allah swt atas suatu tindakan dosa yang dilakukan secara sengaja maupun tidak disengaja. Taubat bersifat wajib, karena pada hakikatnya manusia adalah tempatnya salah dan dosa. Zuhud merupakan kosongnya hati dari cinta terhadap dunia. Sedikitnya dunia yang dimiliki belum tentu menjadikan seseorang termasuk orang yang zuhud. Banyaknya dunia yang dimiliki tidak menutup kemungkinan seseorang menjadi termasuk dalam golongan orang yang zuhud. Sabar adalah sifat yang hanya ada pada manusia sebagai makhluk yang paling sempurna. Sabar terbagi menjadi dua, yaitu sabar jasmani dan rohani. Sabar jasmani yaitu menerima atau tidak melawan ketika mendapat cobaan yang berkaitan dengan jasmani seperti mendapatkan penyakit atau tertimpa musibah. Sabar rohani adalah sabar dalam menahan godaan hawa nafsu, seperti ketika melihat sesuatu yang mendorong pada perbuatan maksiat. Syukur merupakan ungkapan terima kasih atas sesuatu yang datang dengan mempergunakan sesuatu itu dengan sebaikbaiknya. Allah adalah satu-satunya żat pemberi nikmat. Dia-lah yang membuat matahari bersinar, bulan bercahaya sehingga malam menjadi terang. Tidak terhitung berapa banyaknya nikmat yang telah Allah berikan untuk setiap 
makhluknya. Maqam ridha merupakan maqam tertinggi yang dapat dialami oleh orang-orang yang dekat dengan Allah. Maqam ridha hanya dapat dicapai setelah sebelumnya lulus dari maqam taubat, zuhud, sabar, serta syukur. Ridha yaitu menerima dengan sukacita apapun keputusan yang Allah berikan. Ia meyakini dengan hatinya bahwa segala sesuatu yang Allah berikan adalah karena Allah menyayanginya sehingga ia merasa bahagia. Al-Ghazali mengatakan bahwa ridha adalah buah dari rasa cinta (mahabbah).

Kedua, Laku Tasawuf yang digambarkan oleh tokoh Midah dalam novel Mekkah: Memoar Luka Seorang $T K W$ mirip seperti kisah seorang sufi perempuan Rabieah Adawiyah. Midah hidup di tengah keluarga miskin yang agamis. Sejak kecil Midah sudah menjadi anak yang shalihah, selalu menerima setiap cobaan yang menimpanya. Midah menjadi semakin dekat dengan Allah dan selalu hidup dalam kezuhudan. Kedekatannya kepada Allah menumbuhkan cinta yang mendalam di dalam hatinya. Kesibukannya menjadi seorang TKW di Mekkah tidak menyurutkan ibadahnya. Midah justru semakin mendekat kepada Allah disetiap waktu senggangnya.

\section{REFERENSI}

[1] M. S. A. Senali, Tasawuf\&Jalan Hidup Para Wali, Gresik: Putra Pelajar, 2000.

[2] A. H. W. M, Tasawuf yang Tertindas: Kajian Hermeneutik Terhadap Karya - Karya Hamzah Fansuri Cet. Ke-1, Jakarta: Paramadina, 2001.

[3] A. Suryadilaga, Miftahus Sufi, Yogyakarta: Teras, 2007.

[4] A. Semi, Anatomi Sastra, Padang: Angkasa Raya, 1998.

[5] N. Mu'asyara, "Nilai nilai Tasawuf dalam Novel Ayat - Ayat Cinta Karya Habiburrahman El-Shirazy dan Relevansinya dalam Pengembangan Akhlak Al Karimah," Skripsi UIN Walisongo, Semarang, 2014.

[6] A. Irawan, Mekkah Memoar Luka Seorang TKW, Yogyakarta: Glosaria Media, 2014.

[7] M. Lutfi, Hermeneutika: Pemahaman Konseptual dan Metodologis", Surabaya: Jurusan Sastra Indonesia, Fakultas Sastra, UNAIR, 2018.

[8] N. K. Sari, "[Skripsi] Studi Teks Terhadap Makna Aforisme Syair Ikan Tongkol Hamzah Fansuri," UIN Walisongo, Semarang, 2014.
[9] Kaelan, Metode Penelitian Agama: Kualitatif Interdisipliner, Yogyakarta: Paradigma, 2010.

[10] K. Kartono, Metodology Research, Bandung: Mandar Maju, 1990.

[11] Anshari, "Hermeneutik Sebagai Teori dan Metode Interpretasi Makna Teks Sastra," Sawerigading, vol. 15, 2009.

[12] Hamka, Tasawuf: Perkembangan dan Pemurniannya, Jakarta: Pustaka Panjimas, 1984.

[13] A. Syukur, Ilmu Tasawuf II, Surabaya: Bina Ilmu, 1980.

[14] M. S. Anshori, Tasawuf dan Revolusi Sosial, Kediri: Pustaka Azhar, 2011.

[15] M. Kertanegara, Menyelami Lubuk Tasawuf, Jakarta: Erlangga, 2006.

[16] A. Q. A. Q. An-Naisabury, Risalah Qusyairiyah: Induk Ilmu Tasawuf, Surabaya: Risalah Gusti, 2014.

[17] Asnawiyah, "Maqam dan Ahwal: Makna dan Hakikatnya dalam Pendakian Tuhan," SUBTANTIA, vol. 1, 2014.

[18] A. Ghozali and I. Ulumiddin, Cet 1. Penerj. Labib, Jakarta: Republika 2013, 2013.

[19] D. A. Al-Bunny, Mengetuk Pintu-Pintu Langit Shufiyah dengan Kebersihan Jiwa dan Kesucian Hati, Yogyakarta: Mitra Pustaka.

[20] S. M. Amin, Ilmu Tasawuf, Jakarta: Amzah, 2015.

[21] A. N. A. Sarraj, AL-Luma: Rujukan Lengkap Ilmu Tasawuf, terj. Wasmukan dan Samson Rahman, Surabaya: Risalah Gusti, 2002.

[22] S. A. Q. Al-Jailani and D. Afriasi, Jala' Al Khathir: Untaian-Untaian Hikmah dan Wirid Sehari-hari, Yogyakarta: Diva Press, 2013.

[23] A. Azra, Ensiklopedi Tasawuf Cet 1, Bandung: Angkasa, 2008.

[24] A. Q. A. Qusyairy, Risalah Qusyairiyah terj. M. Lukman HAkiem, Surabaya: Risalah Gusti, 2014.

[25] S. J. Nurbakhsy, Belajar Bertasawuf: Mengerti Makna dan Mengamalkan Zikir, Tafakur, Muroqobah, Muhasabah, dan Wirid, Jakarta: Zaman, 2016.

[26] Wasalmi, "Mahabbah Dalam Tasawuf Rabi'ah Al Adawiah," Sulesna, vol. 9, no. 2, 2014.

[27] tirto.id, "Tirto.id," Tirto, 2019. [Online]. Available: http://tirto.id/kpk-nyatakan-walikota-malang-dan-jajarannya-korupsi. [Accessed 11 September 2019]. 
[28] Badan Pengembangan dan Pembinaan Bahasa, "Kbbi," [Online]. Available: https://kbbi.web.id/korupsi. [Accessed 11 September 2019].

[29] H. Bagir, Buku Saku Tasawuf, Bandung: Oase, 2005.

[30] N. Ibrahim, Guru Mursyid Sang Juru Selamat, Bandung: Oase, 2009.
[31] Hamka, Tasawuf Modern, Jakarta: Pustaka Panjimas, 1987.

[32] H. Bagir, Islam Risalah Cinta dan Kebahagiaan, Jakarta: PT Mizan Publika, 2013. 